$12-31-2020$

\title{
Impact of Development-induced displacement on the Tribal community, with special reference to the women in Odisha
}

Debasree De

Department of History, Maharaja Srischandra College, West Bengal, India, debasreede16@gmail.com

Follow this and additional works at: https://scholarhub.ui.ac.id/ajce

Part of the Social and Behavioral Sciences Commons

\section{Recommended Citation}

De, Debasree (2020). Impact of Development-induced displacement on the Tribal community, with special reference to the women in Odisha. ASEAN Journal of Community Engagement, 4(2), 302-320.

Available at: https://doi.org/10.7454/ajce.v4i2.1112

Creative Commons License

(c) (i) ()

This work is licensed under a Creative Commons Attribution-Share Alike 4.0 License.

This Research Article is brought to you for free and open access by the Universitas Indonesia at ASEAN Journal of Community Engagement. It has been accepted for inclusion in ASEAN Journal of Community Engagement. 


\title{
Impact of Development-induced displacement on the Tribal
}

\section{community, with special reference to the women in Odisha}

\author{
Debasree De $\mathrm{a}^{\mathrm{a}^{*}}$

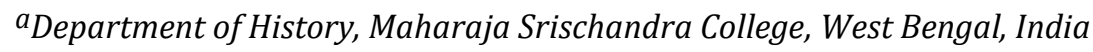

Received: November2nd 2020|| Revised: November $20^{\text {th }} \& 30^{\text {th }}, 2020||$ Accepted: December $22^{\text {nd }}, 2020$

\begin{abstract}
Anti-displacement movements are one of the burning issues in the current global scenario. Global south has been experiencing such widespread resistance since the inception of its anti-colonial struggle. Gender in this context has played a crucial part to make it a large-scale mass movement, as the women bear the brunt of displacement. It is chiefly because they have economic independence as they have customary rights over the communal property resources. Displacement has caused mental trauma for the adivasi women who end up being prostitutes to eke out livelihoods. In this background the present article seeks to explore the impact of development-induced-displacement on the adivasi women of Odisha and analyses their struggle for survival from a socio-historical point of view. The research is based on data collected during the field survey employing a stratified simple random sampling method. The objective of the present research is to understand the changing pattern of livelihood of the adivasi women before and after displacement and how they are coping with the mental trauma caused by their dispossession. In theory, it is believed that the adivasi women enjoy a greater autonomy than their non-adivasi counterparts. But the primary outcome of the research shows that, in the wake of neo-liberal economy, increasing risks of life and deteriorating standard of living due to evictions causing serious problems like loss of assets, alcoholism, wife-battering, and domestic violence. Therefore, the research attempts to analyse the plight of the adivasi women suffering due to the onslaught of destructive "development" and thus taking part in many ongoing movements against displacement.
\end{abstract}

Keywords: Adivasi; women; displacement; resettlement; Vedanta.

\section{Introduction}

A recent report published by The Statesman on August 12, 2019 revealed that 16 states in India, including Maharashtra, Tripura, Karnataka, Chhattisgarh, Goa, West Bengal, Assam, Jharkhand, Rajasthan and others, have admitted before the Supreme Court that they have passed adverse orders against the tribal members and traditional forest dwellers who are facing eviction from a forestland because the state governments have rejected their claims over it (Bharti, 1991; Jewitt; 2008). More or less 11.8 lakh claims over the forestland by the scheduled tribes (STs) have been rejected till date, and eviction orders have been passed to "free" lakhs of hectares of the forestland. These governments have now admitted that irregularities are observed on the part of the authorities in rejecting the claim on "extraneous"

\footnotetext{
*Correspondence Author: debasreede16@gmail.com
} 
Debasree De | ASEAN Journal of Community Engagement | Volume 4, Number 2, 2020

and "incorrect" grounds and agreed to review the orders. They have also admitted that the rejection of claims has not even been communicated to the claimants.

Asian countries record the highest incidence of displacement. The landowners and the state representatives determine the value of land in the market. But two other agents are now getting involved in the negotiation and these are the existing political parties and the civil society. Land acquisition by the state in India for development projects has become the utmost important issue at present (De, 2015). Loss of private land holdings, limited access to productive resources, shrinking economic base, lack of public policy initiatives, shortcomings of legal measures, and continued marginalization have never dissolved the inequality toward the Adivasis. Among the displacing agents like dams, industries and mines, dams occupy the top position. Lands are acquired for both public and private sectors and when it is for private sector it also needs to go through a proper process directed by the state. Although at the macroeconomic level, land acquisition for infrastructure development (e.g., roads, railways, and bridges) is unavoidable, at the microeconomic level, it leads to the displacement of several people mostly residing at the lower strata of the social hierarchy.

In liberalized economy, state sometimes is involved in acquiring land even for private sectors on easy terms and conditions. When the planning commission was set up after India gained independence, land acquisition for development purposes was a regular feature of the Indian government, and neither rehabilitation nor resettlement was virtually considered. The problem in India is that all the sellers of land are not the owners. There are millions of farmers who do not own or possess land, such as the tenants, wage labourers, artisans, and the like. There are also a large number of marginal farmers who possess only a meagre portion of land. They all get excluded from the compensation during the land acquisition. The government used to give a meagre amount to the displaced and sometimes did not even bother to pay. Nehru was quite clear about this factor when it comes to the Adivasis that they should sacrifice their interests for the greater good.

This situation can be described as the "traditional phase" in land acquisition. However, it started changing after the Liberalization, Privatization and Globalization (LPG) policy was introduced in India in the 1990s. This current phase is ripe with resistance and antidisplacement movements; therefore, it is called the "civil society phase." In this period, not only stakeholders but also non-government organizations (NGOs), activists, and media all take part in raising consciousness about a destructive development that produces landless poor. In addition, this phase witnesses grave concerns as far as compensation and 
Debasree De | ASEAN Journal of Community Engagement | Volume 4, Number 2, 2020

rehabilitation packages are concerned (Sathe, 2011; Somayaji \& Dasgupta, 2013). In the current phase, the state has shifted its notion of greater good to a realization that violence cannot work in development. Electronic and social media, along with an advanced communication and information technology, play a critical role in covering the incidents of violence perpetrated against the displaced when land acquisitions take place. The state is now taking an inclusive standpoint while thinking of land acquisition because of the displaced who are willing to give up their land in exchange for an adequate compensation (cash/job) (Sathe, 2016).

However, the growth of a strong civil society in India in conjunction with a vibrant mass media has facilitated the affected people to put up strong anti-neo-colonial resistance to the land acquisition and has increased the visibility of the resulting conflicts (Majumdar, 2008). At the same time, resistance can never be located mono-dimensionally because it is an interactive process. The intricacies and interrelated components must be grasped to situate resistance within the paradigm of social history. Adivasis are struggling to cope with the changing situations around them, be it residing in a resettlement colony or working as unorganized laborers. Their reorientation to these changes, according to Pati (2017) should be a part of their survival strategy that epitomizes resistance. Such survival strategies also go through the onslaught of shifting identities, such as religious conversion, be it Christianity or Hinduism (Pati, 2017).

However, what is of most concern is the fact that the government itself as an institution has always been deeply engaged in violating the spirit of its own tribal land policy since time immemorial. Be it the central or the state governments, neither has demonstrated any empathy toward the problems plaguing the tribal communities of the country till today. On the other hand, the history post-independence India is full of examples of exploitation, deprivation and marginalisation of the tribal population. The model of development pursued by the Indian state since independence has never come up for such sharp scrutiny as, lately, in the context of the magnitude of displacement it has produced and the trauma and impoverishment it has caused to the displaced persons due to the apathy towards their rehabilitation and resettlement. Wherever displacement of population has taken place, in the name of development projects, it is invariably the tribals in general and tribal women in particular who have been compelled to bear the brunt of it. Tribals are not well organised everywhere to rise against such exploitation. 
Debasree De | ASEAN Journal of Community Engagement | Volume 4, Number 2, 2020

The absence of viable alternatives has led the tribal members waging struggle for survival, which can be linked to the problem of land alienation. Resistance through this act of surviving is contested by the might of the neo-colonial state. Their voices are no less thin than the past instead echoing the roar of the colonial era as the colonial era was fraught with numerous tribal uprisings, both violent like Santal insurrection of 1855 and Munda uprising of 18991900 and non-violent like Tana Bhagat, Haribaba in the nineteenth century and the like. Land alienation can be defined in a narrow and in a broad sense (Sharma, 2001). In the narrow sense, it can mean the alienation of individual holdings and means of livelihood. In the broad sense, it includes the loss of common properties and rural commons. Land alienation to individuals can be divided into four cross-cutting categories: alienation in urban and rural areas and tribal to non-tribal and tribal to tribal (Ekka, 2011). Apart from land alienation and poor access to land resources, other factors are also responsible as far as the Adivasi land rights are concerned. For example, forest reservation, loss of dongar or swidden cultivation land, faulty survey and settlement process, and ineffective land reform acts.

The conversion of the Adivasi lands to protected or reserved forestlands has caused severe outrage in Odisha as their right on dongar has become unrecognized. These forestlands are neither surveyed nor are the cultivators given ownership rights. Ergo, if the Adivasis till the land, then they are regarded as illegal encroachers. The initiative on the part of the government to identify landless Adivasis or to distribute land among the landless is virtually zero. Odisha has been declared as a protected area where sanctuaries and national parks are constructed. This declaration has caused hardships for the Adivasis because they can only collect non-timber forest resources and must face restrictions on entering the forest; if they enter, they will be regarded as criminals. In many parts of India, tribal areas have been characterized by the insurgency. Tribal members have been rendered disposable and dispensable in the ensuing violence between the insurgents and the counterinsurgents. It has marred the aspirations of the local Adivasis who are not only fighting against the violation of their customary land rights but also are against the destruction of their local institutions and practices, which are immanent to their identity (Hebbar, 2018; Sankar, 2016). This process of criminalization of the poor Adivasis has caused their dissatisfaction, which is translating into violence and conflicts (Kar, 1999; Kumar, 2011).

Land gives a sense of belonging to humans and provides a life support system to subaltern people. Land also has a significant impact on the life and livelihood of tribal members and Dalits. Understanding the reserve value of land, people always attempt to possess it as much 
as possible. However, the shape of class struggle likely becomes different for Adivasis and Dalits (Shah, 2018). Banerjee (2016) argued that while Dalits have articulated themselves as political subjects through representation, Adivasis have done so through autonomy. In the process of land grabbing, the poor tribal members have been affected more than others. Due to their acute poverty, supernatural beliefs, and backwardness, the tribal people fall easy prey to moneylenders, traders, and exploiters. With the opening of tribal areas to the non-tribal members and to the state, the process in the name of development thereupon adopted in tribal economy has resulted in large-scale land alienation from tribal land to non-tribal members or to the state.

Displacement is also caused by natural calamities. Manmade displacement occurred only when the state tries to "modernize" the traditional societies. The shift to a neo-liberal economy and its inclusion into the global economic order has broadened the scale of acquisition of land and escalated its speed. This kind of displacement are planned and therefore anticipated. Development-induced-displacement is essentially permanent because the land required for development is usually huge in proportion and thus the magnitude of displacement is bound to be gigantic. Besides, the land is situated not in the cities but in the rural areas. The people in these rural areas are completely dependent on their land for subsistence. So, with the acquisition of land they lose their livelihood alternative. The state overrides the consent of the oustees and at the end of the day whatever compensation is paid to the displaced, if any, is not satisfactory at all. The enactment of Special Economic Zones in 2005 has added a new dimension to the demand for acquisition of land in terms of regions, sites, measure, and topographical nature. In this way land acquisition is gradually becoming coercive and insensitive causing destruction and trauma of the people affected. People have been resisting to such acquisition spontaneously, but the state repression and incarceration have shown the real face of "development".

Tribal members alienate from their age-old land due to their inability to discharge the loan liabilities incurred by them or due to the policy inadequacies, which cannot retain land with the tribal members. This situation may also be due to state interventions in tribal areas in the name of development. This relentless war of the master race still attempts to "civilize" primitive men. Women are worst hit by the so-called boon of development, modernity, and civilization. The terror unleashed by development causes impoverishment for them without having any knowledge about when it is going to visit to their own land. 
Debasree De | ASEAN Journal of Community Engagement | Volume 4, Number 2, 2020

The current Eurocentric model of development has become synonymous with progress and modernization, which is the realm of the urban elite of our society. For the Adivasis, it is still the realm of rhetoric that transmits through the inequitable phenomenon of displacement without adequate compensation and rehabilitation (Fernandes, 2004). A well-established fact is that women bear the hardest brunt of the changes in livelihood pattern during displacement and have less access to the benefits of development than their male counterparts. These women have become the flag bearer of the grassroot social movements and thus their role should be judged from a feminist perspective.

After independence, the first and foremost objective of the government was land acquisition for large-scale industrialization. It led to a significant change in the land use pattern, following mass displacement with or without rehabilitation worth mentioning, which is still going on unabatedly. This reason explains why the Adivasi women are now spearheading several anti-displacement movements across the nation. State violence has been unleashed against these innocent Adivasis to curb the discontent and resume the so-called normalcy, which, in a way, ignites discontent and protest and de-popularizes the notion of "inclusive growth." Women have always been at the forefront, be it protest Vedanta, Tata, Utkal Alumina International Limited, Pohang Steel Corporation, Bharat Aluminium Company in Gandhamardan, and Integrated Shrimp Farm Project in Chilika.

A complete dearth of comprehensive research on the gendered aspect of forced displacement is observed; therefore, its impact on the Adivasi women has never been dilated in detail. The problem is that tribal societies do not have a well-defined system of land ownership - the reason why they are deprived of the just compensation. They usually do not have patta of their traditional land holdings. Ergo, they only care about their access to the landed resources. Therefore, the research intends to explore the gender discourse of development-induced displacement. It also examines the context, trajectories, and nature of their participation in the resistance vis-à-vis development initiatives during the neoliberal regime. In addition, the study seeks to answer questions such as "how do women experience displacement and relocation in the Adivasi society?" and "does displacement affect women differently?" These aspects are analysed from our case study.

\section{Methods}

In this article, we attempted to analyse the sociological impact of displacement on the Adivasi women by drawing essential information from 50 Adivasi women whom we selected 
through the stratified random sampling method. Their narratives were recorded during the field study conducted in Damanjodi, Koraput District of Odisha in July 2019-August 2019. We attempted to revisit their memories and lived experiences in the wake of displacement by National Aluminium Company limited (NALCO). It undertakes an attempt to focus on the opinion of the Adivasi women about how they coped with the change and what is their perspective of the rehabilitation packages, if any. Qualitative methods were used, such as field visit, participatory observation, group discussion, and structured interview guide with a scheduled questionnaire. The study is essentially based on the ethnographic narratives of the women in the area under study.

\section{Results and Discussion}

Most development projects have been executed in resource-rich tribal areas. Large-scale deforestation and mining activities have eventually resulted into massive displacement. Nevertheless, the Adivasis have underwent multiple forms of displacement, which have left them with few alternatives. For example, most oustees of Hindustan Aeronautics Limited in Koraput District, who were displaced in the 1960s for the first time, faced the trauma of a second displacement in the 1980s due to the construction of the Upper Kolab Multipurpose Dam Project; they were displaced for the third time because of the establishment of the Naval Armament Depot and agricultural farms (Jena, 2014). Similarly, the oustees of Hirakud Multipurpose Dam Project, who were displaced in the mid-1950s and resettled in the Brajarajnagar area of Jharsuguda District, faced displacement for the second time due to the construction of the IB Thermal Power Station in the late 1980s and some others because of the IB Valley Coal Mining Project in 1980-1990 (Das, 2011; Dias, 2012). The Adivasis constitute the most disproportionate sacrificing community and are the victims of development, which has unjustly appropriated the natural habitation by its commercial interests.

Involuntary evictions have brought about profound socioeconomic and cultural disruption to the victims of dislocation. Women have always experienced displacement in a certain way in which gender division of labour is inherent and consistent. Specifically, this gender division of labour has a long history of induction of men into the traditional wage earning and labourintensive workforce, whereas women are tied to land and household activities. Our research is based on empirical findings corroborated by the lived experiences of the evicted Adivasi women on loop. From the shared thoughts and everyday life stories of the respondents, 
Debasree De | ASEAN Journal of Community Engagement | Volume 4, Number 2, 2020

alternative voices are becoming louder than before to represent the marginalized sections of the society. However, as far as the mainstream discourses are concerned, gender-as a category of debates - is yet to be recognized and thus leads to the homogenization of the displaced as a single category, thereby diluting its differential nature.

Forced rehabilitation seriously affects the survival strategy and adaptive system of the displaced people (DP) in general and women. These relocation programs do not encourage local participation in the decision-making process. According to Shiva (1993), “Women's underdevelopment was not due to insufficient and inadequate participation; rather it was due to their enforced but asymmetric participation whereby they bore the cost but were excluded from the benefits." Such exclusionary measures, insensitive toward women, scarcely give vent to the special requirement of the displaced committees. It leaves a huge gap between the policymakers and the incumbents who never lead to attain the original standard of living of the oustees. Given that the Adivasi women are the upholders of the traditional cultural practices of their society, their well-being is affected when evictions endanger their identity, destabilize their poise, and expose them to a new and unknown environment not befitting their way of life, if not hostile, without having negotiated their space and role.

One of the reasons for their marginalization is the level of education among the Adivasi women in India. A recent report published in The Times of India by the National Statistical Office (75th round) reveals that STs are even worse than the Muslims as far as their literacy is concerned. The report shows that the literacy rate among Muslim men is equivalent to that of Dalits and higher than the rate among the tribal members. The literacy rate among Muslim women is higher than that among Dalit and tribal women. Above the higher secondary level, the Gross Attendance Ratio (GAR) is also above the tribal members. The report reveals that among such members, the literacy rate is $77 \%$ for men and $61 \%$ for women. The GARs for tribal members are 101\% primary, 90\% upper primary, 80\% secondary, 53\% higher secondary, and 14\% above higher secondary. Tribal children aged between 3-35 years, who have never enrolled, are $15 \%$ male and $22 \%$ female.

The Adivasi women have always been considered as an invisible workforce and the Adivasi economy as "uneconomic." Such notions have downplayed the role of the Adivasi women as contributors to the subsistence economy because it is not underscored by the theories of market economy. With the sudden encounter with the vagaries of the consumer economy after being compensated via cash money, most of the displaced households lose the track of how to expend them in a fruitful way or for that matter in a productive way. Perforce, 
mere cash compensation can neither restore the lost productive assets nor the lost dignity of the evicted. The way rehabilitation packages are implemented has been proved detrimental for the most vulnerable sections of the society. "Sustainable" development has become a mockery, which does not address the real issues pertaining to the actual betterment of the poor and powerless people; primarily among them are the Adivasi women.

After displacement, the Adivasi women lose their free space of social interaction that they used to enjoy before. They are now confined and forced to lead a monotonous urban life inside the four walls of rehabilitation camps. They also lose all their economic independence and rights over communal property resources (CPRs) and end up being housewives bereft of the traditional skills and knowledge. Given that no compensation is paid for the loss of CPRs, it builds a certain sense of loneliness and insecurity followed by stress and trauma (Nathan, 2009). The relocation process is fraught with disempowerment and impoverishment, and the reconstruction of resources remains half-hearted and incomplete. Gender inequality and discrimination are embedded in our society, both of which are used as exclusionary mechanisms for the state to nix the right of women to participate in the consultation process held during the Gram Sabha meetings; their consent never matters.

Risks of chronic poverty and powerlessness are also accentuated. Considering that women rarely exercise ownership right, they easily become left out. It forces them to join the unorganized sector as wage laborers and sometimes even become prostitutes. In unhealthy shabby urban slums, women face all sorts of domestic violence that are unthinkable in a tribal culture. Increase in alcoholism due to the mental trauma makes their life miserable. The male members, as the unquestionable heads of households and having all the monetary compensation on their names, emerge as the owners of women's fate. These male members strengthen the patriarchal acculturation by pushing back the womenfolk at the backstage.

The transitional period between the physical dislocation and material resettlement is the most difficult time (Cernea, 1999; 2000). The Adivasi women are the most affected while the shifting work is in progress. They lose jobs, homes, and even a family support system. Thus, they lose their distinct separate identity and internalize the mainstream role of non-Adivasi housewives. Their nutritional status and health condition also go through a major dip. As far as the Rehabilitation and Resettlement ( $\&$ R) is concerned, the new act called Land Acquisition, Rehabilitation and Resettlement (LARR) has homogenized all land-based communities and diluted the differences within tribal and non-tribal societies. It has also played a dominant role in delineating the pitfalls of the new laws. 
Debasree De | ASEAN Journal of Community Engagement | Volume 4, Number 2, 2020

The interview conducted in this study highlights that the experiences of the internally displaced Adivasi women are fundamentally disenfranchising, majority of whom is forcibly displaced. Rehabilitation camps retain all sorts of discriminations and insensitivities that women face in their daily life. The following field study report attempts to analyse the way Adivasi women are perceived as non-people and thus brings a new insight into their everyday experiences. The grim faces of the helpless and superfluous internally evicted women are everywhere in rehabilitation colonies where they must spend a life of a destitute without any human rights in a stateless situation. Endemic violence and marginalization are their everyday companion. Being uprooted from their community life, these women lose their individuality and eventually identity and end up being identified as "victims of development." This homogenization marks the collapse of their agency and representation, making them powerless and epitomizing gender discrimination, subjugation, and rightlessness.

In our patriarchal state system, women are categorized as non-subjects. The emerging focus on the internally displaced Adivasi women in the policy framework reveals that the evicted women fall prey to the patriarchal dominance and coercion. The immanent vulnerability and the oppressive condition in rehabilitation colonies compel them to become ensnared by recruiting agents who send them to unknown places for work and thus women suddenly "disappear" and never come back. The clear indifference on the part of the government increases their susceptibility to trafficking. As previously mentioned, being involuntarily displaced is not a homogeneous category. Note that women experience dispossession in a particularly gendered way (Lahiri-Dutt, 2012). The need to use the gendered lens determines gender as a category of analysis as it is a cogent identity. Moreover, indigenous people are the ones persecuted in the name of nation-building projects. Their lands are being termed as national sacrificing zones.

As far as the gender discourse is concerned, the best battlefield is the home itself. With displacement, the male members of households lose their identity as the sole "providers" or "breadwinners," revealing that women are forced to take up jobs in the unorganized sector. It increases insecurity among these men and thus domestic violence incidents escalate. This factor has been particularly detrimental to the Adivasi women's autonomy. They are left with no option except fulfilling the survival needs of their family. This coping mechanism has opened new vistas for the Adivasi women to recuperate their lost agency and to create new space for themselves. 
The Adivasi women have proven that they are no longer the "passive victims" of development-induced displacement and can be united for a greater cause, that is, to demand a better package in the form of resettlement or compensation. They have an innate sense of self-worth, which is quite evident in their reminiscences. They continue to demonstrate different degrees of resistance. Displacement entails a psychosocial trauma, which transforms the structural balance of the Adivasi culture or way of life and disempowers their womenfolk.

Case Study: Koraput is a mineral rich district of South Odisha. In this district, Panchpatmali hill range is the largest deposit of bauxite where opencast mining has been conducted for decades. NALCO has also built-up Asia's largest integrated aluminum complex in this district. The refiner is situated at Damanjodi. We visited the Koraput Block, which had been severely affected by the mining project of NALCO and experienced massive displacement. Our fieldwork was conducted in Damanjodi Village in 2019. We spoke to 50 respondents from 20 families, all Adivasi women, those who belong to the Kondh community, and those between the 25-55 age groups. The total number of members in these 20 families is 112 . Among these 20 families, 18 are DP, and two are project-affected people. These 18 families were sent to the resettlement camp at Amalabadi. The two other families did not receive any housing and chose to remain at their native place. A graph, which demonstrates the marital status and literacy rate of the respondents, is provided below (Tables 1 and 2). The changing nature of assets and that of occupational distribution are presented in Tables 3 and 4, respectively.

Table 1. Marital Status of the Respondents

\begin{tabular}{ccc}
\hline Marital status & $\begin{array}{c}\text { Number of } \\
\text { respondents }\end{array}$ & Percentage \\
\hline Married & 31 & $62 \%$ \\
Unmarried & 12 & $24 \%$ \\
Divorcee/Separated & 01 & $2 \%$ \\
Widow & 06 & $12 \%$ \\
\hline
\end{tabular}

Table 2. Literacy Rate of the Respondents

\begin{tabular}{ccc}
\hline Level of education & $\begin{array}{c}\text { Number of } \\
\text { respondents }\end{array}$ & Percentage \\
\hline $\begin{array}{c}\text { Primary (up to 5th } \\
\text { standard) }\end{array}$ & 10 & $20 \%$
\end{tabular}


Debasree De | ASEAN Journal of Community Engagement | Volume 4, Number 2, 2020

\begin{tabular}{ccc}
\hline Level of education & $\begin{array}{c}\text { Number of } \\
\text { respondents }\end{array}$ & Percentage \\
\hline $\begin{array}{c}\text { Upper primary (up } \\
\text { to 8th standard) }\end{array}$ & 8 & $16 \%$ \\
$\begin{array}{c}\text { Secondary (up to } \\
\text { 10th standard) }\end{array}$ & 5 & $10 \%$ \\
Higher secondary \\
$\quad$ (up to 12th \\
standard)
\end{tabular}

Table 3. Changing Nature of Assets

\begin{tabular}{cccccc}
\hline $\begin{array}{c}\text { Sl. } \\
\text { No. }\end{array}$ & Asset & $\begin{array}{c}\text { Pre-displacement } \\
\text { period }\end{array}$ & $\begin{array}{c}\text { Percent } \\
\text { age }\end{array}$ & $\begin{array}{c}\text { Post-displacement } \\
\text { period }\end{array}$ & $\begin{array}{c}\text { Percent } \\
\text { age }\end{array}$ \\
\hline 1 & Kutcha house & 32 & $64 \%$ & 12 & $24 \%$ \\
2 & Pucca house & 18 & $36 \%$ & 38 & $76 \%$ \\
3 & Own land & 24 & $48 \%$ & 00 & $0 \%$ \\
4 & Shareholder & 18 & $36 \%$ & 11 & $22 \%$ \\
5 & Landless & 26 & $52 \%$ & 50 & $100 \%$ \\
6 & Grazing ground & 22 & $44 \%$ & 00 & $0 \%$ \\
7 & CPRs & 45 & $90 \%$ & 00 & $0 \%$ \\
8 & Cash & 00 & $0 \%$ & 24 & $48 \%$ \\
\hline
\end{tabular}

Before displacement, most of the Adivasi families used to live in mud houses or kutcha houses, and only three families had their own brick houses. After displacement, NALCO provided them with pucca houses with $10 \times 10$ feet structures. No space was provided for homesteads, livestock rearing place or grazing ground; no place for storage or drying of agricultural products; and no place for gardening and roof materials. Before displacement, the 
Adivasi families used to have enough space for grazing animals. Several women also used to work in their own land, whereas others used to work as agricultural laborers. However, after losing their lands to NALCO, they are bound to work mostly as agricultural laborers on other fields, and most women have retired from their jobs such as weeding, transplanting, threshing, and harvesting. They are now living as housewives inside concrete camps.

These women have even lost their collection work because forests are being cut down. NALCO had an environmental regeneration scheme under which thousands of trees have been planted, but they have remained inaccessible to the displaced as they are commercial in nature. Families who had patta have received some cash money as compensation, but they are all in the name of their men. They received Rs. 2500/per acre for paddy land and Rs. 1000/per acre for dry land. All fertile lands were lost to NALCO. No compensation was paid for the loss of CPRs, severely affecting women. Thus, landlessness and joblessness increased their hardships manifold during the displacement.

Table 4. Changing Nature of Occupational Distribution

\begin{tabular}{cccccc}
\hline $\begin{array}{c}\text { Sl. } \\
\text { No. }\end{array}$ & Occupation & $\begin{array}{c}\text { Pre-displacement } \\
\text { period }\end{array}$ & $\begin{array}{c}\text { Percen } \\
\text { tage }\end{array}$ & $\begin{array}{c}\text { Post-displacement } \\
\text { period }\end{array}$ & $\begin{array}{c}\text { Percent } \\
\text { age }\end{array}$ \\
\hline 1 & Agriculture & 42 & $84 \%$ & 11 & $22 \%$ \\
2 & Service & 02 & $4 \%$ & 02 & $4 \%$ \\
3 & Business & 02 & $4 \%$ & 03 & $6 \%$ \\
4 & Self-employed & 04 & $8 \%$ & 04 & $8 \%$ \\
5 & No occupation & 00 & $0 \%$ & 25 & $50 \%$ \\
6 & Subsidiary & 38 & $76 \%$ & 05 & $10 \%$ \\
\hline
\end{tabular}

Before displacement, a substantial number of female respondents were engaged in agricultural activities. They either worked on their own land or on others' land as laborers. They somehow survived in agriculture. Two women worked as schoolteachers before displacement, and they continue working after displacement. Two other women sold liquor at a local market before displacement, and they still do after getting displaced. Four women were engaged in collection work and leaf plate making. Almost every family used to collect fuel and fodder from the nearest forest before displacement. The collection work cannot be separated from agricultural activities as women do both in the Adivasi society. However, after 
Debasree De | ASEAN Journal of Community Engagement | Volume 4, Number 2, 2020

displacement, women are confined in rehabilitation camps. No cattle wealth is left inside the camps; thus, they no longer need to collect fodder. Deforestation also causes disaster for the collection work. Significantly, no unemployed women existed before displacement and were engaged in direct or indirect jobs. However, after displacement, the unemployment rate rose. No government initiative has been taken so far in this regard.

Table 5. Percentage of Loss and Gain

\begin{tabular}{cccc}
\hline Sl. No. & Loss and gain & $\begin{array}{c}\text { Number of } \\
\text { respondents }\end{array}$ & Percentage \\
\hline 1 & Job opportunity & 05 & $10 \%$ \\
2 & Skill development & 15 & $30 \%$ \\
3 & Vocational training & 15 & $30 \%$ \\
4 & Drinking water & 48 & $96 \%$ \\
5 & Electricity & 48 & $96 \%$ \\
6 & Education & 05 & $10 \%$ \\
7 & Formation of Self-help & 15 & $30 \%$ \\
8 & Groups & 00 & $0 \%$ \\
9 & Health care & 00 & $0 \%$ \\
10 & Celebration of festivals & 00 & $0 \%$ \\
\hline
\end{tabular}

During the interview, the respondents shared that NALCO failed to provide any job to women (Table 5). Five women do some head-loading work in the mines as mere unskilled laborers. NALCO has opened a training center as a part of their corporate social responsibility program where 15 women are given vocational trainings, such as sewing. For drinking water, NALCO has provided some tube wells and taps, but they are insufficient. Women still go to rivers and streams every day to collect water. During summer, water crisis becomes acute. Electricity has been given partially. No medical facility or healthcare facility has been provided. A camp school is built but it is of poor standard. Note that the displaced families did not have any loans prior to the displacement, but they are now borrowing loans to start new businesses because livelihood risks are high. They are even devoid of any sorts of modern amenities, savings, and comfort in the rehabilitation colony. 


\section{Conclusion}

Development theory is polymorphic as this doctrine has assumed myriad shades of connotations and significances irrespective of time and space. Development-induced displacement panders the systematic exploitation of the weak sections and shores up the existing power structure in which the benefits flow from the periphery to the centre. The Adivasi women neither have on-project employment because of the mechanization nor are added to the official employment records of the government. Displacement compels people to become fragmented and to migrate by breaking all social and familial ties. The place where they are meant to settle down temporarily, as outsees may go through multiple displacements, is completely new, having everything out of place. It leads to a social disruption as the Adivasi community life becomes affected and disjointed. Moreover, the spree of macro-development projects treats them like nothing but victims of development.

The participation of the Adivasi women in resistance movements have always been consistent and worth reckoning. The concept of patriarchy can be defined broadly as the control of men on the production and reproduction capacity of women. The Adivasi women of today are exercising their agency and can articulate autonomy as a free movement without any interference. They are quite aware of the exploitation and suppression perpetuated by multinational corporations and the state time and again. The power of the state in development initiatives has drastically reduced and has thus become a grave concern. The ability of the state to provide social democratic safeguards has been dwindling since the early 1990s. Its role has shifted from the protector to the partner of private capital in this entire process of displacement. In the past, rehabilitation of the oustees received much greater attention than the nature of development per se which causes compulsory land acquisition resulting in displacement and destabilization. This is because the recent mobilization of the displaced people demanding proper rehabilitation does not bring these agencies into direct confrontation with the state or the dominant sections of the society which could be the case if they were to question the nature of development itself which induces development. Thus, development is required, but what is required more is that it should be 'sustainable' in nature. The 'gains' from the development should be much more than the 'pains'.

After losing their source of livelihood and spiralling on a downward mobility path, the Adivasi women can no longer utilize their former skills in the new environment; therefore, human capital is wasted or transformed into unproductive or is left inactive. They lose confidence in themselves and thus a drastic fall occurs in their social status. The pain inflicted 
Debasree De | ASEAN Journal of Community Engagement | Volume 4, Number 2, 2020

by dislocation and an untrammelled victimization gradually depreciates the self-respect of the outsees and stigmatizes their social position. Their right to disagree is being constantly threatened by the global corporate greed, including their own local collaborators. Finally, the study has attempted to highlight the gender dimension of development-induced displacement, its impact on tribal women, and the experience of the relocation policy by the displaced women. The research has also focused on how the long-term impoverishment of tribal women perpetuates and creates social tension and financial instability and insecurity. Despite several constitutional and legal measures, people are being forcibly evicted from all over the country in the name of "sustainable" development. This study has enabled us to reduce the degree and magnitude of displacement and has highlighted the vices of destructive development per se. In sum, movement against displacement has become a life-struggle for the adivasi women. The Dongria Kondh women of Niyamgiri Hills took part in the gram sabha hearings to convey their opinion which has been acknowledged even by the Supreme Court. Their dedication and contribution to the movement have opened new vistas of gendering movement against forced eviction and dispossession. They have championed the cause of introducing proper rehabilitation and resettlement measures. It has led to the enactment of The Right to Fair Compensation and Transparency in Land Acquisition, Rehabilitation and Resettlement Act in 2013 which, despite a lot of loopholes, has been considered a significant event.

\section{Acknowledgement}

The research is funded by the Indian Council of Social Science Research (ICSSR) Impactful Policy Research in Social Science (IMPRESS) of Ministry of Human Resource Development, Government of India, and is based on a field survey in Koraput and Kalahandi Districts.

\section{Author Contribution}

Debasree De conceived the present idea, developed the theory, and performed the computations. She has verified the analytical methods, investigated, and supervised the findings of this work. She has discussed the results and contributed to the final manuscript. 


\section{References}

Alpa, S., Lerche, J., Axelby, R., Benbabaali, D., Donegan, B., Raj, J., \& Thakur, V. (2018). Ground Down by Growth. Tribe, Caste, Class, and Inequality in Twenty-First Century India. Pluto Press and Oxford University Press (India). https://eprints.soas.ac.uk/25886/

Banerjee, P. (2016). Writing the Adivasi: Some Historiographical Notes. Indian Economic and Social History Review, 53(1), 1-23.

https://www.csds.in/uploads/custom_files/1526966373_Writing\%20the\%20Adivasi.pdf

Bharti, I. (1991). Bihar's Dams, Tribals' Woes. Economic and Political Weekly, 26(22-23), 13851388.

https://www.epw.in/journal/1991/22-23/roots-specials/bihar-s-dams-tribalswoes.html

Cernea, M. M. (Ed.), (1999). The Economics of Involuntary Resettlement: Questions and Challenges. Washington DC: World Bank, 11. https://doi.org/10.1596/0-8213-3798-X

Cernea, M. M. (2000). Risks, Safeguards and Reconstruction: A Model for Population Displacement and Resettlement. Economic and Political Weekly, 35(41), 3659-3678. https://www.epw.in/journal/2000/41/special-articles/risks-safeguards-andreconstruction.html

Das, A. (2011). Displacement: The Indian State's War on its Own people. Sanhati. https://revolutionaryfrontlines.wordpress.com/2011/10/03/displacement-the-indianstate\%E2\%80\%99s-war-on-its-own-people/

De, D. (2015). Development-induced displacement: impact on adivasi women of Odisha. Community Development Journal, 50(3) 448-462. https://doi.org/10.1093/cdj/bsu053

Dias, A. (2012). Development and its Human Cost. Jaipur: Rawat Publications.

Dwivedi, R. (1998). Resisting Dams and Development: Contemporary significance of the campaign against the Narmada Projects in India. European Journal of Development Research, 10(2), 135-179.

https://www.tandfonline.com/doi/abs/10.1080/09578819808426721

Ekka, A. (2011). A Status of Adivasis/Indigenous Peoples Land Series-4. 
Debasree De | ASEAN Journal of Community Engagement | Volume 4, Number 2, 2020

Fernandes, W. (2004). Rehabilitation Policy for the Displaced. Economic and Political Weekly, 39(12), 21-27. https://www.epw.in/journal/2004/12/commentary/rehabilitationpolicy-displaced.html

Guha, R. (Eds.), (1982). Subaltern Studies I. Delhi: OUP.

Hebbar, R. (2018). Reframing the Debate: The Tribal Question and Contemporaneity.In Savyasaachi (Ed.), Intractable Conflicts in Contemporary India, Narratives and Social Movements. New Delhi: Routledge.

Jena, B. K. (2014). Development-Induced Displacement in 21 $1^{\text {st }}$ Century India. Proceedings of the Indian History Congress, 75, 1183-1191. https://www.jstor.org/stable/44158508

Jenny, R. (Ed.), (2002). Development and Displacement. New Delhi: Oxford University Press.

Jewitt, S. (2008). Political Ecology of Jharkhand Conflict. Asia Pacific Viewpoint,49(1), 68-82. https://shodhganga.inflibnet.ac.in/bitstream/10603/37053/11/11_chapter\%202.pdf

Kar, G. C. (1999). Displacement, Resettlement and Rehabilitation. Orissa Economic Journal, 30(1 and 2), 19. http://www.orissaea.in/Journal/Journal_2018.pdf

Kumar, K. A. (2011). A Status of Adivasis/Indigenous Peoples Land Series-2. https://www.researchgate.net/profile/Sricharan_Behera/publication/232062516_Status _of_AdivasisIndigenous_Peoples_Land_Series_-

_Orissa/links/5836bcd008ae503ddbb54b0f/Status-of-Adivasis-Indigenous-PeoplesLand-Series-Orissa.pdf

Lahiri-Dutt, K. R. K., \& Nesar, A. (2012). Land Acquisition and Dispossession: Private Coal Companies in Jharkhand. Economic and Political Weekly, 47(6), 39-45. https://www.jstor.org/stable/41419821?seq=1

Majumdar, B. (2008). Forced Industrialization and Workers' Struggle: Some Recent Evidence from India. Indian Journal of Labour Economics, 51(4), 1001-14. http://www.universalreview.in/assets/uploads/doc/d2e88-316-328.universal_28.pdf

Nathan, D. (2009). Social Security, Compensation and Reconstruction of Livelihoods. Economic and Political Weekly, 44(30), 22.

https://www.epw.in/journal/2009/30/commentary/social-security-compensation-andreconstruction-livelihoods.html 
Debasree De | ASEAN Journal of Community Engagement | Volume 4, Number 2, 2020

Oliver-Smith, A. (2010). Defying Displacement: Grassroot resistance and the critique of development. Austin: University of Texas Press.

https://www.academia.edu/download/32487318/Ensor_AA_-_Defying_Displacement.pdf

Pati, B. (2017) Survival, Interrogation and Contests Tribal Resistance in Nineteenth Century Odisha. In Uwe Skoda and Biswamoy Pati (Eds.), Highland Odisha Life and Society Beyond the Coastal World. Delhi: Primus Books.

Prasad, P. H. (1996). Dynamics of Neo-Colonial Exploitation. Economic and Political Weekly, 31(12), 719-722. https://www.jstor.org/stable/i397263

Sankar, T. L. (2016). The Rights of Tribals over Their Land. In K. B. Saxena and G. Haragopal (Eds.), Marginalization, Development and Resistance, Vol. II. New Delhi: Aakar.

Sathe, D. (2011). Political Economy of Land and Development in India. Economic \& Political Weekly, 151-155. https://www.jstor.org/stable/23018738?seq=1

Sathe, D. (2016). Land Acquisition Need for a Shift in Discourse. Economic \& Political Weekly, 51(51), 52-58.

https://www.epw.in/journal/2016/51/special-articles/land-acquisition.html

Shah, G. (1990). Social Movements in India: A Review of Literature. New Delhi: Sage. http://library.mpib-berlin.mpg.de/toc/z2009_2844.pdf

Sharma, C. K. (2001). Tribal Land Alienation: Government's Role. Economic and Political Weekly, 36(52), 4791-4795.

https://www.researchgate.net/publication/336563396_Tribal_Land_Alienation_in_Assa m_Government's_Role

Shiva, V. (1993). Impoverishment of the environment: Women and children last in Mies, M. Shieva, V. (Eds.), Ecofeminism. London, United Kingdom: Zed Books.

Somayaji, S., \& Dasgupta, S. (Eds.), (2013). Sociology of Displacement: Policies and Practice. New Delhi: Rawat Publications. 